\title{
Replace of the EPOST glyphosate with pre herbicides and application of different LPOST glyphosate rates for weed control in established vine- yard
}

\author{
Zvonko PACANOSKI ${ }^{1}{ }^{2}$, Krum BOŠKOV ${ }^{1}$, Arben MEHMETI ${ }^{3}$
}

Received October 05, 2020; accepted November 22, 2020.

Delo je prispelo 05. oktobra 2020, sprejeto 22. novembra 2020.

Replace of the EPOST glyphosate with pre herbicides and application of different LPOST glyphosate rates for weed control in established vineyard

Abstract: Two-year field trials were conducted at two winegrowing districts (Kavadarci and Skopje in 2016 and 2017) to evaluate wheather oxyfluorfen, pendimethalin and flazasulfuron can replace early post-emergence (EPOST) application of glyphosate in established vineyard until its application in early summer period. The weed vegetation in vineyards in both years was consisted mainly of Chenopodium album L., Setaria viridis (L). Beauv., Papaver rhoeas L., Xanthium strumarium L., Lolium multiflorum Lam., Sorghum halepense (L.) Pers. and Cynodon dactylon (L.) Pers. Pendimethalin, oxyfluorfen and flazasulfuron efficiently reduced predominant annual weeds and $S$. halepense seedlings in 2017, but not in 2016. PRE herbicides, regardless year, had no significant effect on $C$. dactylon. Opposite, the efficacy of EPOST applied glyphosate was significantly lower in 2017 compared to 2016. LPOST glyphosate applied at 2.0 1 ha $^{-1}$ provided at least $94 \%$ control of dominant annual broadleaf and grass weeds. LPOST application of glyphosate at $2.0 \mathrm{l} \mathrm{ha}^{-1}$ and glyphosate at 2.0 and $4.01 \mathrm{ha}^{-1}$ resulted in unsatisfactory weed control of predominant perennial S. halepense, and C. dactylon, respectively. LPOST glyphosate applied at $4.01 \mathrm{ha}^{-1}$ provided control of $S$. halepense by $84 \%$ or more. LPOST glyphosate applied at 8.01 ha $^{-1}$ reduced the amount of $S$. halepense and C. dactylon at least 97 $\%$. Grapevine yield of both varieties was not lower in all herbicide treatments in 2016 compared with 2017. However, yield in the PRE herbicide treatments $\mathrm{fb} 2.0$ and $4.01 \mathrm{ha}^{-1}$ glyphosate was collectively $15-19 \%$ and $17-19 \%$ lower compare to PRE herbicide treatments fb $8.01 \mathrm{ha}^{-1}$ glyphosate and standard two applications of glyphosate, respectively for both years and districts. No impacts to grapevine growth were observed from PRE herbicide treatments at either district. trol

Key words: established vineyard; weeds; herbicides; weed con-
Zamenjava EPOST glifosta s $s$ tretiranjem $\mathrm{z}$ izbranimi herbicidi pred kalitvijo plevelov in uporaba različnih odmerkov LPOST glifosta za uravnavanje plevelov $v$ vinogradu

Izvleček: Dvoletni poskus je bil izveden v dveh vinogradniških območjih Severne Makedonije (Kavadarci in Skopje, 2016 in 2017) za ovrednotenje zgodnje poletne uporabe herbicidov oksifluorfena, pendimetalina in flazasulfurona kot nadomestilo kasnejše uporabe glifosata (EPOST) v ustaljenem vinogradu. Plevelno vegetacijo v vinogradu so $\mathrm{v}$ obeh letih poskusa sestavljale v glavnem naslednje vrste: bela metlika (Chenopodium album L.), zeleni muhvič (Setaria viridis (L). Beauv.), poljski mak (Papaver rhoeas L.), navadni bodič (Xanthium strumarium L.), mnogocvetna ljulka (Lolium multiflorum Lam.), divji sirek (Sorghum halepense (L.) Pers.) in prstasti pesjak (Cynodon dactylon (L.) Pers.). Pendimetalin, oksifluorfen in flazasulfuron so učinkovito zavrli rast predvsem enoletnih plevelov in divjega sirka v letu 2017, in ne v letu 2016. PRE herbicidi niso imeli ne glede na leto nobenega značilnega vpliva na prstasti pesjak. Nasprotno je bil učinek EPOST uporabe glifosata v letu 2017 značilno manjši v primerjavi z letom 2016. LPOST uporaba glifosata v odmerku 2,0 1 ha $^{-1}$ je najmanj za $94 \%$ zavrla dominatne enoletne širokolistne in travnate plevele. LPOST uporaba glifosata v odmerkih 2,0 in 4,0 1 ha $^{-1}$ je bila neučinkovita pri zatiranju trajnih plevelov kot sta divji sirek in prstasti pesjak. LPOST uporaba glifosata v odmerku 4,01 ha $^{-1}$ je zavrla divji sirek več kot $84 \%$. Uporaba LPOST glifosata $\mathrm{v}$ odmerku 8,01 ha $^{-1}$ je zmanjšala zapljeveljenost $\mathrm{z}$ divjim sirkom in prstastim pesjakom za najmanj $97 \%$. Pridelek grozdja obeh sort se v letu 2016 ni zmanjšal zaradi uporabe herbicidov v primerjavi z letom 2017. Kljub temu se je pridelek pri obravnavanju s PRE herbicidi v odmerkih 2,0 in 4, 1 ha $^{-1}$ glifosata skupno zmanjšal za 15-19 \% in 17$19 \%$ v primeri z obravnavanjem s PRE herbicidi v odmerku 8,0 l ha $^{-1}$ glifosata in standa rdno uporabo glifosata $\mathrm{v}$ obeh letih in na obeh območjih. Na rast vinske trte ni imelo obravnavanje s PRE herbicid nobenega vpliva na obeh območjih.

Ključne besede: ustaljen vinograd; pleveli; herbicidi; uravnavanje plevelov

1 Ss. Cyril and Methodius University, Faculty of Agricultural Sciences and Food, Skopje, Republic of North Macedonia

2 Corresponding author, e-mail: zvonkop@zf.ukim.edu.mk

3 University of Prishtina, Faculty of Agriculture and Veterinary, Hasan Prishtina”, Prishtinë, Republic of Kosovo 


\section{INTRODUCTION}

In Republic of North Macedonia weeds management system in established vineyard based on multiple applications of glyphosate, which is required to maintain effective weed control throughout the season. Another approach that may improve weed control and aid in the stewardship of glyphosate use is to apply a pre-emergence (PRE) herbicides prior to a single late post-emergence (LPOST) application of glyphosate. However, to prevent yield loss due to competition with weeds is required a high efficacy of herbicides against weeds during the critical weed control period of different crops (Knežević et al., 2002). This is an important component of an Integrated Weed management (IWM) system and is a major factor in deciding the optimal timing of herbicide application (Swanton et al., 1999; Boerboom, 2000). In established vineyard, early season weed control is important (Mitchem and Monks, 2005), because vigorous weed growth may allow economically important weed species to reduce grape vine growth and yields by competing for water, nutrients- and sunlight (Kadir and Al-Khatib, 2006). In addition, weed competition can impair berry quality and interfere with the harvest (Zabadal and Dittmer, 1994). Studies have shown that full-season competition due to unmanaged weeds could cause reductions in grapevine yield of up to $37 \%$, cane mass of up to $68 \%$, in number of clusters per vine of up to $28 \%$, and in berry mass of up to 3 \% (Byrne and Howell, 1978 cit. by Sanguankeo et al., 2009).

Although cultivation, mowing, and mulching are important weed-management practices in grape vine production (Pool et al., 1990; Kadir et al., 2004), herbicides, particularly use of glyphosate, are the major components of a weed-control program in this crop (Kaps and Odneal, 1991; Kadir and Bauernfeind, 2005). The reliance on glyphosate for weed control in established vineyard in Republic of North Macedonia based on effective weed control throughout the season. But, glyphosate lacks residual soil activity (Baylis, 2000), and multiple applications may be required to provide adequate control of weed species throughout the season (Nurse et al., 2006). The possibility of glyphosate resistance in some weed species (Boerboom and Owen, 2006) means stewardship of glyphosate use will be important to reduce the reliance on this herbicide mode of action for weed control (Lopes Ovejero et al., 2013). An alternative approach that may reduce the amount of glyphosate used and improve season long weed control is the application of a pre-emergence residual herbicide prior to the in crop application of glyphosate (Monsanto Company, 2005).
A few soil applied pre-emergence herbicides are currently registered for use in established vineyard in R. N. Macedonia. Among them, pendimethalin, oxyfluorfen, and flazasulfuron are the most frequent applied. There is limited information whether oxyfluorfen, pendimethalin and flazasulfuron can replace early post-emergence (EPOST) application of glyphosate in established vineyard until its LPOST application in early summer period.

Pendimethalin, a dinitroaniline, and oxyfluorfen a diphenyl ether, are selective pre- and postemergence herbicides that are used to control many annual broadleaf weeds and grasses in many crops including, vineyards (Kaps and Odnea 1991; Mitchem and Monks, 2005; Patil et al., 2008; Alister et al., 2009). Flazasulfuron is a new, recently registered selective, systemic sulfonylurea in viticulture in R. N. Macedonia. It may be used as a pre- or early post-emergence herbicide at very low rates $0.15-0.201 \mathrm{ha}^{-1}$ and has a wide herbicidal spectrum (Tomlin, 2000; Grove, 2011). Pendimethalin, oxyfluorfen, and flazasulfuron are lipophilic, with a $\log K_{\text {ow }}$ of 5.18, 4.47 and 1.30, respectively (Đurović et al., 2008; Anonymous, 2012). This chemical property is associated with a strong organic soil adsorption that results in limited soil mobility (Ying et al., 2000; Barba et al., 2003; Yen et al., 2003; Leak, 2013). Soil residual activity may be maintained for 10-15 weeks (Dev et al., 1992; Raimondi et al., 2010; Grey and McCullough, 2012), but, late germinating weeds may not be controlled satisfactorily. Nonetheless, in an established vineyard pendimethalin, oxyfluorfen, and flazasulfuron may replace early post-emergence (EPOST) application of glyphosate until its late post-emergence LPOST application in full vegetative growth stages (vigorously growing) of perennial weeds, but limited data exists about that.

Therefore, the main objectives were (i) to determine whether acceptable weed control of oxyfluorfen, pendimethalin and flazasulfuron applied PRE may replace EPOST application of glyphosate in established vineyard until the early summer when usually LPOST glyphosate is applied, and (ii) to evaluate efficacy of different LPOST glyphosate rates depending on the weed species in the established vineyard flora.

\section{MATERIALS AND METHODS}

The field trials were conducted in years 2016 and 2017 on commercial established vineyards at Kavadarci and Skopje wine-growing district in central and northern Macedonia, on vertisol and chromic cambisol, respectively (Filipovski, 2006) (Table 1). The experimen- 
Table 1: Soil characteristics of the field trials in the wine growing regions of Kavadarci and Skopje district

\begin{tabular}{lllllll}
\hline Region & Soil & coarse & fine sand & clay + silt \% & organic matter & pH-water \\
\hline Kavadarci & Vertisol & 3.5 & 30.0 & 60.3 & 2.4 & 7.2 \\
Skopje & Chromic cambisol & 10.4 & 41.7 & 40.5 & 2.6 & 6.4 \\
\hline
\end{tabular}

Table 2: Treatments, trade names, rates and time of application of herbicides in the wine growing regions of Kavadarci and Skopje district in 2016 and 2017

\begin{tabular}{llll}
\hline Treatments & Trade name & Rate & Time of application \\
\hline Pendimethalin $455 \mathrm{~g} \mathrm{l}^{-1}$ & Stomp Aqua & $5.0 \mathrm{lha}^{-1}$ & PRE - em \\
Oxyfluorfen $240 \mathrm{~g} \mathrm{l}^{-1}$ & Goal & $6.01 \mathrm{ha}^{-1}$ & PRE - em \\
Flazasulfuron $250 \mathrm{~g} \mathrm{l}^{-1}$ & Chikara & $0.21 \mathrm{ha}^{-1}$ & PRE - em \\
Glyphosate $360 \mathrm{gl}^{-1}$ & Dominator & $3.01 \mathrm{ha}^{-1}$ & EPOST- em \\
Glyphosate $360 \mathrm{gl}^{-1}$ & Dominator & $2.01 \mathrm{ha}^{-1}$ & LPOST - em \\
Glyphosate $360 \mathrm{~g} \mathrm{l}^{-1}$ & Dominator & $4.01 \mathrm{ha}^{-1}$ & LPOST - em \\
Glyphosate $360 \mathrm{gl}^{-1}$ & Dominator & $8.01 \mathrm{ha}^{-1}$ & LPOST - em \\
Control & - & - & - \\
\hline
\end{tabular}

Abbreviations: PRE - pre-emergence; EPOST - early-post-emergence; LPOST - late-post-emergence

tal design was a randomized complete block with four replicates.

The trials were conducted in different sites of the same vineyards in 2016 and 2017. Both sites were spontaneously populated by Papaver rhoeas L., Chenopodium album L. Setaria viridis L., Xanthium strumarium L., Lolium multiflorum Lam., Sorghum halepense (L.) Pers. and Cynodon dactylon (L.) Pers. 'Cabernet Sauvignon' and 'Black Magic' grape vines were used at Kavadarci district and Skopje district, respectively. The vineyards were established in 2010 at a spacing of $1.0 \mathrm{~m}$ between vines and $2.3 \mathrm{~m}$ between rows. The vineyard was drip irrigated, with sprinklers available for frost protection. Drip irrigation and fertilization were applied uniformly across all treatments, based on conventional practices for commercial production.

Herbicides were applied in-row (width $1.0 \mathrm{~m}$ ) with a $\mathrm{CO}_{2}$-pressurized backpack sprayer calibrated to deliver $300 \mathrm{l} \mathrm{ha}^{-1}$ aqueous solution at $220 \mathrm{kPa}$.

Prior to the commencement of the trials, diquat (dibromide salt as Di-Quattro ${ }^{\oplus}, 200 \mathrm{~g}^{2}$ a.i. $\mathrm{l}^{-1}$, Agriphar S.A., Belgium) was applied at $2.01 \mathrm{ha}^{-1}$ to control present established weeds. The PRE herbicide treatments were applied in the early spring, March 3 and February 26 at Kavadarci district and March 8 and March 1 at Skopje district in 2016 and 2017, respectively, when grapevines were still in dormancy. The LPOST application included different rates $\left(2.0,4.0\right.$ and $\left.8.01 \mathrm{ha}^{-1}\right)$ of glyphosate (isopropylamine salt). The LPOST glyphosate (isopropylamine salt) treatments were applied 84 days after PRE application (one day before EPOST glyphosate application), i.e. in full vegetative growth stages (vigorously growing) of perennial weeds. For efficacy comparison, two applications of glyphosate (standard application) were made; initially with $3.0 \mathrm{l}$ $\mathrm{ha}^{-1}$ when weeds were $10-12 \mathrm{~cm}$ tall (EPOST), and repeated with $8.01 \mathrm{ha}^{-1} 45$ days after EPOST glyphosate application (one day before LPOST glyphosate application), i.e. in full vegetative growth stages (vigorously growing) of perennial weeds (LPOST). Untreated control was included in the studies, as well.

The control plots were left untreated during the entire experimental period. Grapevine injury was visually evaluated based on a $0=100 \%$ rating scale, where $0 \%$ is no injury to grapevine plants, and $100 \%$ is complete collapse of grapevine (Frans et al., 1986). Grapevine injury was estimated 28 and 56 days after PRE treatments. Weed control efficacy was estimated 84 days after PRE applications, 45 days after EPOST glyphosate application, and 28 days after LPOST application of different glyphosate rates from $1 \mathrm{~m}^{2}$ area within each plot at both district during two-year experimental period. Herbicide efficacy was calculated by equitation (Chinnusamy et al., 2013):

where:

$$
\mathrm{W}_{\mathrm{CE}}=\frac{\text { Wup }- \text { Wtp }}{\text { Wup }}
$$

$\mathrm{W}_{\mathrm{CE}}$ - weed control efficiency

Wup - number of weeds in the untreated plots

Wtp - number of weeds in the treated plots 
Table 3: Total monthly precipitation and average air temperature from February to October in the wine growing regions of Kavadarci and Skopje district in 2016 and 2017 and average year 1990-2010

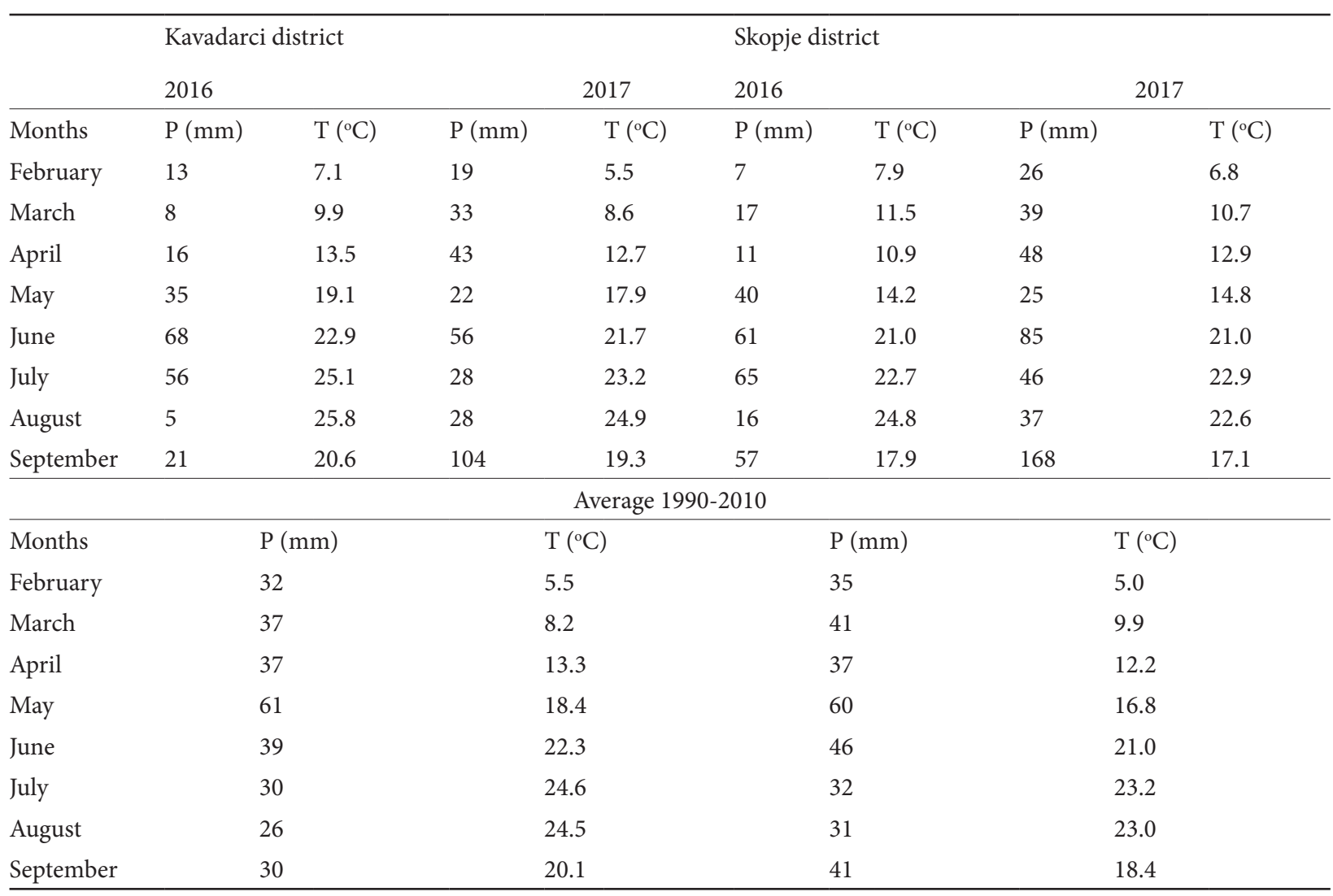

Abbreviations: $\mathrm{P}$ - precipitations; T - temperature

Number of grape cluster per vine, cluster mass and grape vine yield of 'Cabernet Sauvignon' and 'Black Magic' were measured in four vines that were randomly selected within each experimental unit. The grapes harvested on the wine were counted and weighed on site. Number of grape clusters, their mass and grape vine yield were determined when all the experimental units reached the minimum harvest criterion (i.e., at full maturity), in July for 'Black Magic", and in September for 'Cabernet Sauvignon', respectively.

Total monthly rainfalls are shown in Table 2 . The early spring of 2016 was dry in both districts. Precipitations in February, March and April were very low (13, 8 and $16 \mathrm{~mm}$ in Kavadarci district, and 7, 17 and $11 \mathrm{~mm}$ in Skopje districts). However, May, June (especially), and even July were unusually wet months. Opposite, spring of 2017 was humid. Precipitation occurred during February, March and April were a little bit above the average for both districts. In Kavadarci district, precipitation occurred during the three days in the middle of February, and during the first two and the last four days of March. In April and May, it rained on seven and nine days at intervals throughout each month, respectively. In June, precipitation occurred in the second decade of the month. Similar, in Skopje district same year, precipitation occurred in the third decade of February, and at the end of the first and beginning of the second decade of March. In April and May, it rained on seven and ten days at intervals throughout each month, respectively. Summer months in 2017, particularly June, were very humid, $53 \%$ above the 30 years average for the Skopje district $(110 \mathrm{~mm})$.

All treatments in both years were applied at times when herbicide applications typically occur in North Macedonia vineyard production.

The data from both years were combined, tested for homogeneity of variance and normality of distribution (Ramsey and Schafer, 1997) and were log-transformed as needed to obtain roughly equal variances and better symmetry before ANOVA was performed. Data were transformed back to their original scale for presentation. Data were pooled across locations and years and means were separated by using LSD test at $5 \%$ of probability. 


\section{RESULTS AND DISCUSSION}

\subsection{WEED CONTROL}

Weed density 56 days after PRE herbicide application in nontreated control plot was 98 and 148 plants/ $\mathrm{m}^{2}$ in 2016 and 2017, respectively, at Kavadarci district, and 113 and 178 plants $/ \mathrm{m}^{2}$ in 2016 and 2017, respectively, at Skopje district. Efficacy of PRE herbicides and EPOST applied glyphosate varied among weed species, treatments and years, respectively. Inconsistent weather patterns between the 2 years of the study likely influenced the weed control. Limited precipitation after PRE application may have contributed to the poor performance of PRE herbicides at both districts in 2016 (Table 3). Opposite, the humid spring in 2017 (Table 3), and continuous new weed plants emergence, particularly following EPOST glyphosate application, probably was the most likely reason for lower efficacy of EPOST applied glyphosate in 2017 compared to its application in 2016 at both districts (Table 4 and 5).

\subsubsection{Chenopodium album}

The interaction between treatment and year in two distinct years showed significant results for control of C.album in Kavadarci district with PRE herbicides and EPOST glyphosate application, contrary C. album control not showed significant results among years for different LPOST glyphosate application. In Kavadarci district in 2016, pendimethalin, oxyfluorfen and flazasulfuron provided satisfied efficacy of C. album between 69 and $82 \%$. Opposite, all PRE herbicides provided greater efficacy than $84 \%$ of C. album 84 days after PRE treatments in 2017 at the same district (Table 4). Similar, pendimethalin alone or with lower rates of flumioxazin, controlled C. album between 82 and $87 \%$ (Taylor-Lovell et al., 2002), and oxyfluorfen provided C. album control from 88 to 95 \% (Jursík et al., 2011). The differences in control of C. album between 2016 and 2017 demonstrated that inadequate or delayed precipitation can reduce PRE herbicide effectiveness and decrease weed control (Armel et al., 2003; Lyon and Wilson, 2005; Stewart et al., 2012). LPOST application of glyphosate, regardless rates and years, increased $C$. album control up to $100 \%$. EPOST applied glyphosate provided 95 and $88 \%$ control of C. album in 2016 and 2017, respectively. The higher precipitation in the spring 2017, may have promoted late emergence of $C$. album plants It is widely known that glyphosate is used in combination with PRE herbicide (Lopes Ovejero et al., 2013), because does not have residual control, there- fore would not have controlled late emerging plants of this weed. It was concluded that PRE herbicide treatments followed by different efficacy of LPOST glyphosate applications, was the most effective for controlling C. album in both 2016 and 2017.

\subsubsection{Setaria viridis and other weed species}

The interaction between treatment and year in two distinct years showed significant results for control of $S$. viridis and other weed species in Kavadarci district with PRE herbicides and EPOST glyphosate application. S. viridis and other weed species control did not differ between years for different LPOST glyphosate applications. At Kavadarci district in 2016, S. viridis and other weed species control was between 70 and $77 \%$ with pendimethalin and oxyfluorfen. The greatest control was achieved with flazasulfuron (80-83 \%) (Table 4). In 2017, pendimethalin and oxyfluorfen controlled S. viridis and other weed species 86 to $93 \%$, and flazasulfuron 94 to $98 \%$. Obtaining the greatest weed control in the plots treated with flazasulfuron was not surprising, because flazasulfuron has longer residual activity than pendimethalin and oxyfluorfen and good grass weed control (Nieto et al., 1998; Singh et al., 2012). Control of $S$. viridis and other weed species improved after the LPOST glyphosate applications ranging from 99 to $100 \%$ and 98 to $100 \%$ in 2016 and 2017, respectively. From the other side, control of S. viridis and other weed species ranged 94 to $87 \%$ for EPOST glyphosate application in both years (Table 4). The lower control ratings of $S$. viridis and other weed species in 2017 compared to 2016 may have been the result of more precipitation, which have promoted late weed emergence after the EPOST glyphosate application.

\subsubsection{Papaver rhoeas}

The interaction between treatment and year in two distinct years showed significant results for control of P. rhoeas with PRE herbicides and EPOST glyphosate application at both districts, but $P$. rhoeas control did not differ between years for different LPOST glyphosate applications, as well. Flazasulfuron controlled $P$. rhoeas more than pendimethalin and oxyfluorfen 84 DAT (Tables 4 and 5). At Kavadarci district flazasulfuron controlled $P$. rhoeas by 83 and $85 \%$ in 2016. Bonasia et al. (2012) reported similar levels of $P$. rhoeas control in lampascione - (Muscari comosum (L.) Mill.) with flazasulfuron. Pendimethalin and oxyfluorfen did not control P. rhoeas more than 78 and $77 \%$, respectively the same 
year. Because PRE herbicides require precipitation to move into the zone of active weed seeds germination, an increase of precipitation in 2017 in compare with 2016, may explain the variability among PRE treatments. Flazasulfuron, pendimethalin, and oxyfluorfen had 12 to $19 \%$ higher efficacy of $P$. rhoeas compared to the same treatments previous year (Table 5). Similar, at Skopje district efficacy of PRE herbicides significantly lower in 2016 compare to 2017. Pendimethalin, oxyfluorfen and flazasulfuron controlled $P$. rhoeas slightly better than did same herbicides at Kavadarci district in 2016, but provided similar efficacy in 2017 (Table 4). Efficacy of EPOST applied glyphosate was significantly lower in 2017 compared to 2016, because of humid spring, which have promoted late emergence of $P$. rhoeas plants and lacks of glyphosate soil activity. However, application of different rates of LPOST glyphosate provided consistent control of $P$. rhoeas (95-100 \%) at both districts and in both years (Tables 4 and 5).

\subsubsection{Sorgum halepense}

A significant treatment by year interaction resulted in two distinct years for $S$. halepense control in Kavadarci district with PRE herbicides and EPOST glyphosate application. S. halepense control did not differ among years for different LPOST glyphosate applications. In 2016 pendimethalin and oxyfluorfen provided no more than $76 \%$ control of S. halepense seedlings (Table 4). Flazasulfuron provided significantly higher efficacy (79-88 \%) in control of S. halepense seedlings. In 2017, all PRE treatments provided greater control of $S$. halepense. Pendimethalin provided at least $80 \%$ control of $S$. halepense seedlings. In investigations of Grey and Webster (2013), pendimethalin provides $90 \%$ control of $S$. halepense seedlings. S. halepense seedlings control ranged from 78 to $82 \%$ with oxyfluorfen. Flazasulfuron provided control as good as or better than did pendimethalin and oxyfluorfen (92-93\%). McGovern et al. (2010) found similar results with flazasulfuron applied at 0.025 and $0.050 \mathrm{~kg} /$ ha a.i., which produced very good initial S. halepense control at 30 DAA (95\%) that was maintained through 90 DAA (93 and $90 \%$ control), respectively. EPOST application of glyphosate at $3.01 \mathrm{ha}^{-1}$ reduced $S$. halepense by 90 and $84 \%$ in 2016 and 2017, respectively. Opposite, the lowest LPOST glyphosate application $\left(2.01 \mathrm{ha}^{-1}\right.$ ) did not control S. halepense more than $52 \%$, while LPOST glyphosate applied at $4.01 \mathrm{ha}^{-1}$ provided control of $S$. halepense by $84 \%$ or more, 28 DAT. The highest rate of LPOST glyphosate $\left(8.01 \mathrm{ha}^{-1}\right)$ provided $100 \% \mathrm{~S}$. halepense control, in each year.

\subsubsection{Xanthium strumarium}

A significant treatment by year interaction resulted in two distinct years for X. strumarium control in Skopje district with PRE herbicides and EPOST glyphosate application, but $X$. strumarium control did not differ among years for different LPOST glyphosate applications (Table 4). Pendimethalin, oxyfluorfen and flazasulfuron provided inconsistent control of $X$. strumarium and varied greatly between years and PRE treatments (ranging from 53 to $89 \%$ control). Variability in control between years demonstrated that less rainfall before and, particularly after the PRE applications in 2016 did not dissolve the herbicides in soil water solution so that they could not be taken up by the emerging weeds after germination (Novosel et al., 1998; Chomas and Kells, 2004). Pendimethalin, oxyfluorfen and flazasulfuron provided 53 to $78 \%$ X. strumarium control in 2016, but in 2017 the same PRE treatments controlled X. strumarium 73 to $89 \%$. Opposite, efficacy of the EPOST glyphosate was significantly higher in 2016 than in 2017. However, LPOST glyphosate treatments consistently provided the highest levels of $X$. strumarium control, between 94 and $100 \%$ (Table 5).

\subsubsection{Lolium multiflorum}

A significant treatment by year interaction resulted in two distinct years for L. multiflorum control in Skopje district with PRE herbicides. However, L. multiflorum control did not differ among years for EPOST and different LPOST glyphosate applications (Table 5). In 2016, PRE herbicides provided control of L. multiflorum between 75 and $83 \%$. Control improved in 2017, because Skopje district received 22 and $37 \mathrm{~mm}$ more precipitation in March and April, respectively compared to same months in 2016. It is likely that these humid conditions contributed to the increased efficacy of PRE herbicides. Pendimethalin provided at least $91 \%$ control of L. multiflorum. Alshallash (2014) reported for effective control of L. multiflorum with pendimethalin. L. multiflorum control ranged from 86 to $93 \%$ with oxyfluorfen, while flazasulfuron provided control better than did pendimethalin and oxyfluorfen (96-100\%). Excellent control with flazasulfuron was expected as this herbicide provides excellent control of this species (Nieto et al., 1998). Control of L. multiflorum improved after the LPOST glyphosate applications, particularly in 2016, ranging from 95 to $100 \%$ and 97 to $100 \%$ in 2016 and 2017, respectively. EPOST glyphosate provided $97 \%$ control of L. multiflorum for both years (Table 5). 


\subsubsection{Cynodon dactylon}

C. dactylon control did not differ among years for PRE herbicides, EPOST and different LPOST glyphosate applications (Table 4). PRE herbicides, regardless year, had very poor or no effect on C. dactylon. Control of C. dactylon was less than $41 \%$ and $32 \%$ with any PRE treatment in 2016 and 2017, respectively (Table 5). In general, preemergence herbicides do not control C. dactylon, because the principle means of its propagation is through the rhizomes and stolons (Holm et al., 1977; Kostov, 2006). However, only the highest rate of LPOST glyphosate $\left(8.01 \mathrm{ha}^{-1}\right)$ showed high efficacy for C. dactylon by $97 \%$ or more, 28 DAT in both years. LPOST glyphosate applied at 2.0 and $4.01 \mathrm{ha}^{-1}$, did not control C. dactylon more than 71 and $69 \%$ in 2016 and 2017, respectively. Poor control of C. dactylon was obtained by EPOST glyphosate application, as well, which was ranged 45 to $48 \%$ in both years (Table 5).

\subsection{IMPACT ON GRAPEVINE YIELD}

Number of cluster per vine, cluster mass and grape vine yield of 'Cabernet Sauvignon' and 'Black Magic' at both districts varied among treatments and years, mainly due to poor performance of PRE herbicides in 2016 as well as non sufficient control of perennial weeds, particularly Cynodon dactylon with LPOST glyphosate application at 2.0 and $4.01 \mathrm{ha}^{-1}$ in 2016 and 2017, respectively (Table 6).

Generally, vine yield components were lower in 2016 compared with 2017, but without significant effect years $\mathrm{x}$ herbicides interaction. In 2016 there was significant effect for the number of cluster per vine at both districts, but not effect was recorded in 2017. Herbicide treatments had effect on cluster mass in both years and districts. For example, cluster mass in the PRE herbicide treatments fb 2.0 and $4.0 \mathrm{l} \mathrm{ha}^{-1}$ glyphosate were significantly lower compare with standard two applications of glyphosate and PRE herbicides fb 8.01 ha $^{-1}$ glyphosate, respectively. Grape vine yield was insignificantly lower in all herbicide treatments in 2016 compared with 2017. Yield in the PRE herbicide treatments fb 2.0 and $4.01 \mathrm{ha}^{-1}$ glyphosate was collectively 15-19\% and 17-19\% lower compare to PRE herbicide treatments $\mathrm{fb} 8.01 \mathrm{ha}^{-1}$ glyphosate and standard two applications of glyphosate, respectively for both years and districts. Similar results were obtained by Sanguankeo et al. (2009). In a rainy year, the herbicides treatments did not differ in grape yield, but in a dry year, in herbicide treatments the grape yield reductions was around $22 \%$.

\subsection{IMPACT ON GRAPEVINE GROWTH}

Grapevine growth was ordinary throughout the both growing seasons, and no impacts were observed on vines growth in plots with PRE herbicide treatments at ither district (data not shown). These results are expected because vineyards were well established (since 2010) and their roots were relatively deep in the soil (Kadir et al., 2004). In addition, herbicides used in the study have poor water solubility and leachability (Yen et al., 2003; Leak, 2013). Furthermore, soils at both sites (vertisol and chromic cambisol) contain relatively large amount of silt + clay (60.3 and $40.5 \%$, respectively), which would result in less herbicide leaching.

\section{CONCLUSIONS}

Results of this research demonstrate that the efficacy of PRE herbicides pendimethalin, oxyfluorfen and flazasulfuron in established vineyards are strongly depended by the amount of precipitation and weed population. Limited precipitation after PRE application contributed to the poor performance of these herbicides at both districts in 2016. Therefore, pendimethalin, oxyfluorfen and flazasulfuron effectively reduced predominant Papaver rhoeas, Chenopodium album, Setaria viridis, Xanthium strumarium, Lolium multiflorum and Sorghum halepense in 2017, but not in 2016. This suggests that the application of PRE herbicides for residual weed control is unnecessary and does not improve weed control in comparison to EPOST glyphosate application under dry conditions only. The precipitation amount should be considered when selecting the most appropriate PRE weed management strategy in established vineyard as a replace for the first glyphosate application.

However, there was benefit from the application of the PRE herbicides applied in early spring prior to LPOST glyphosate application in 2017. The excellent weed control afforded by PRE herbicides in this year resulted in very few weeds being present at the time of LPOST glyphosate applications.

Because of that, stewardship of glyphosate use will be important to reduce the reliance on this herbicide mode of action for weed control in established vineyard. Preceding glyphosate application with PRE herbicides may also replace the application of EPOST glyphosate until its LPOST application in the full vegetative growth stages (vigorously growing) of perennial weeds, i.e. in early summer period. 


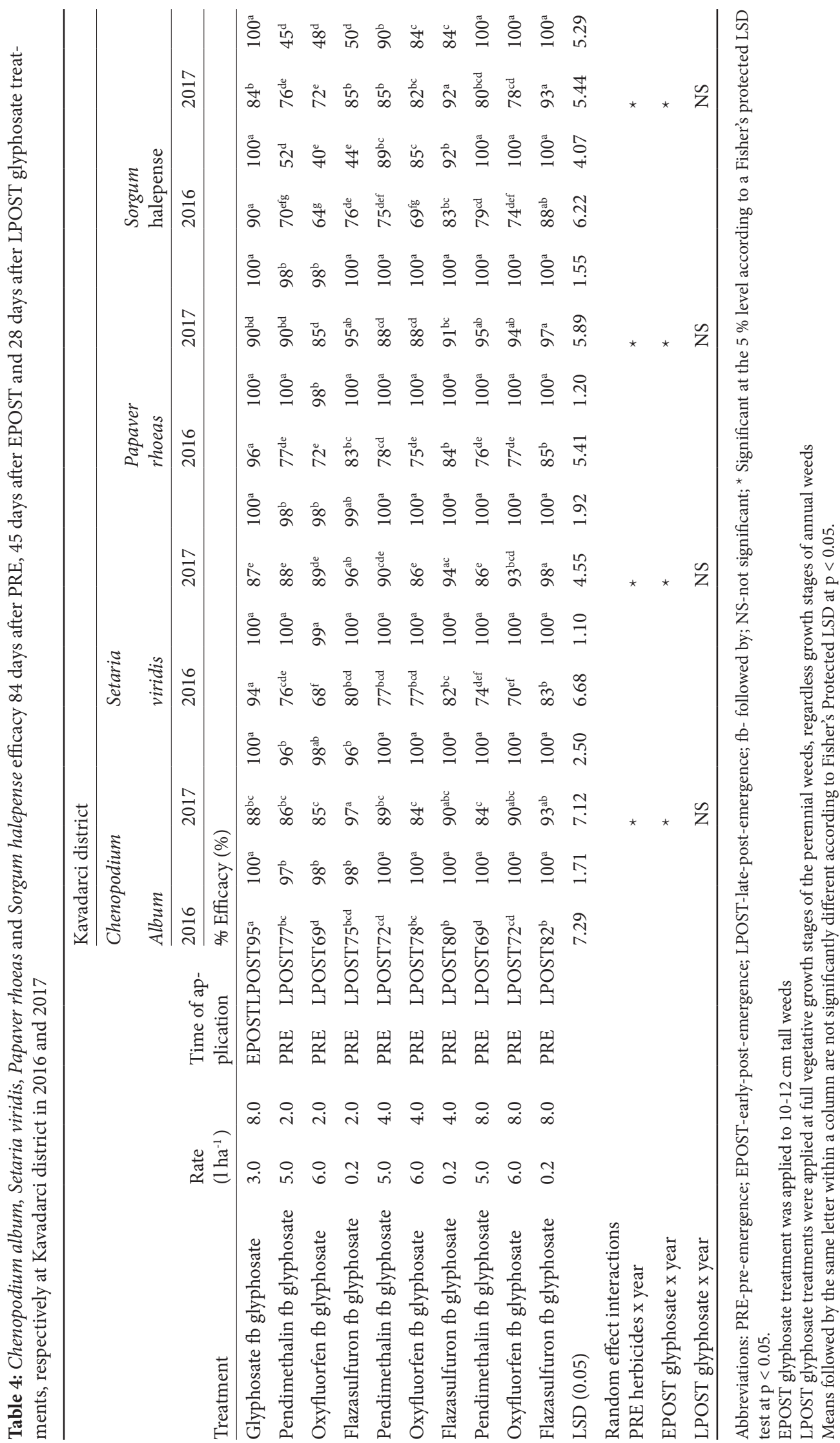




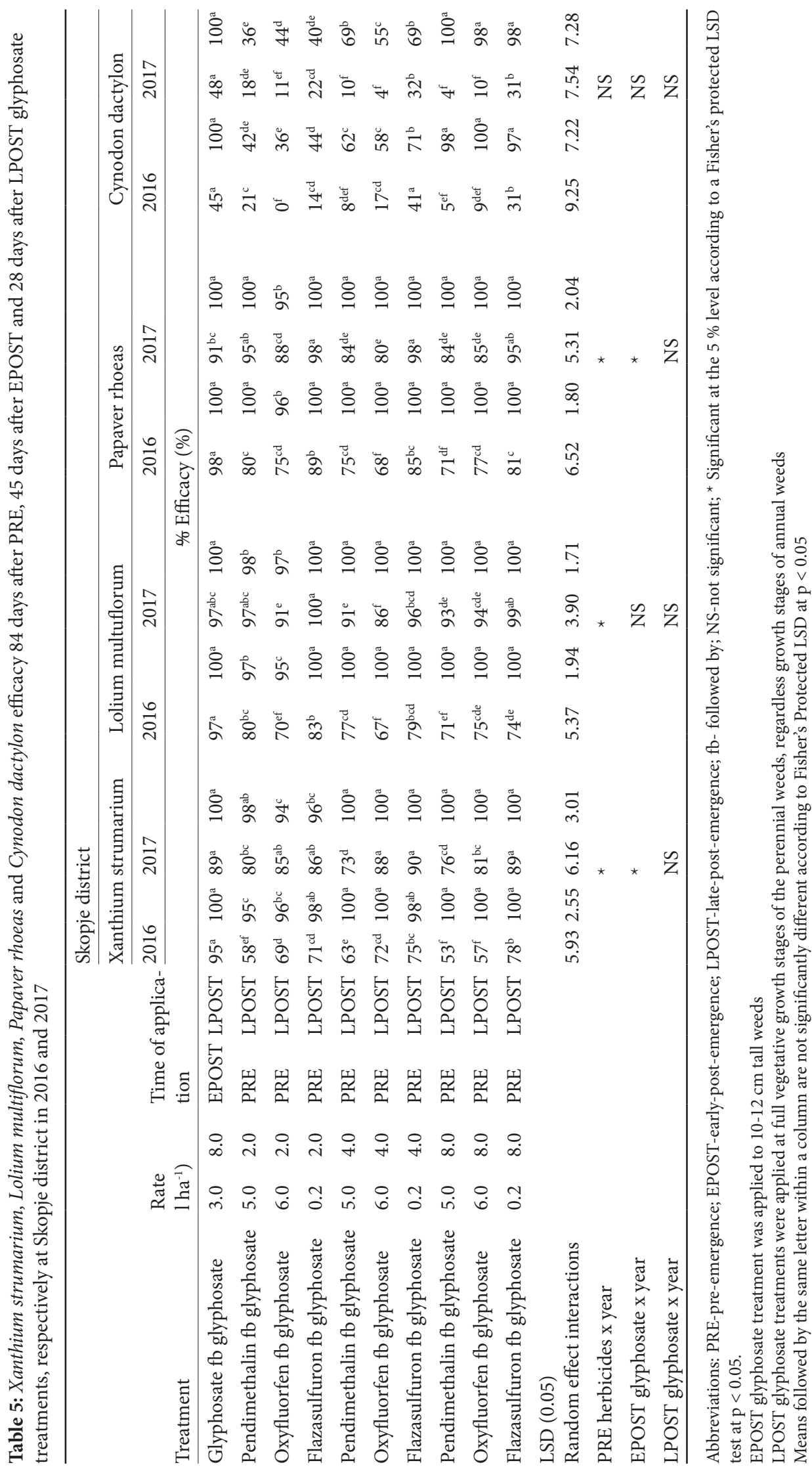




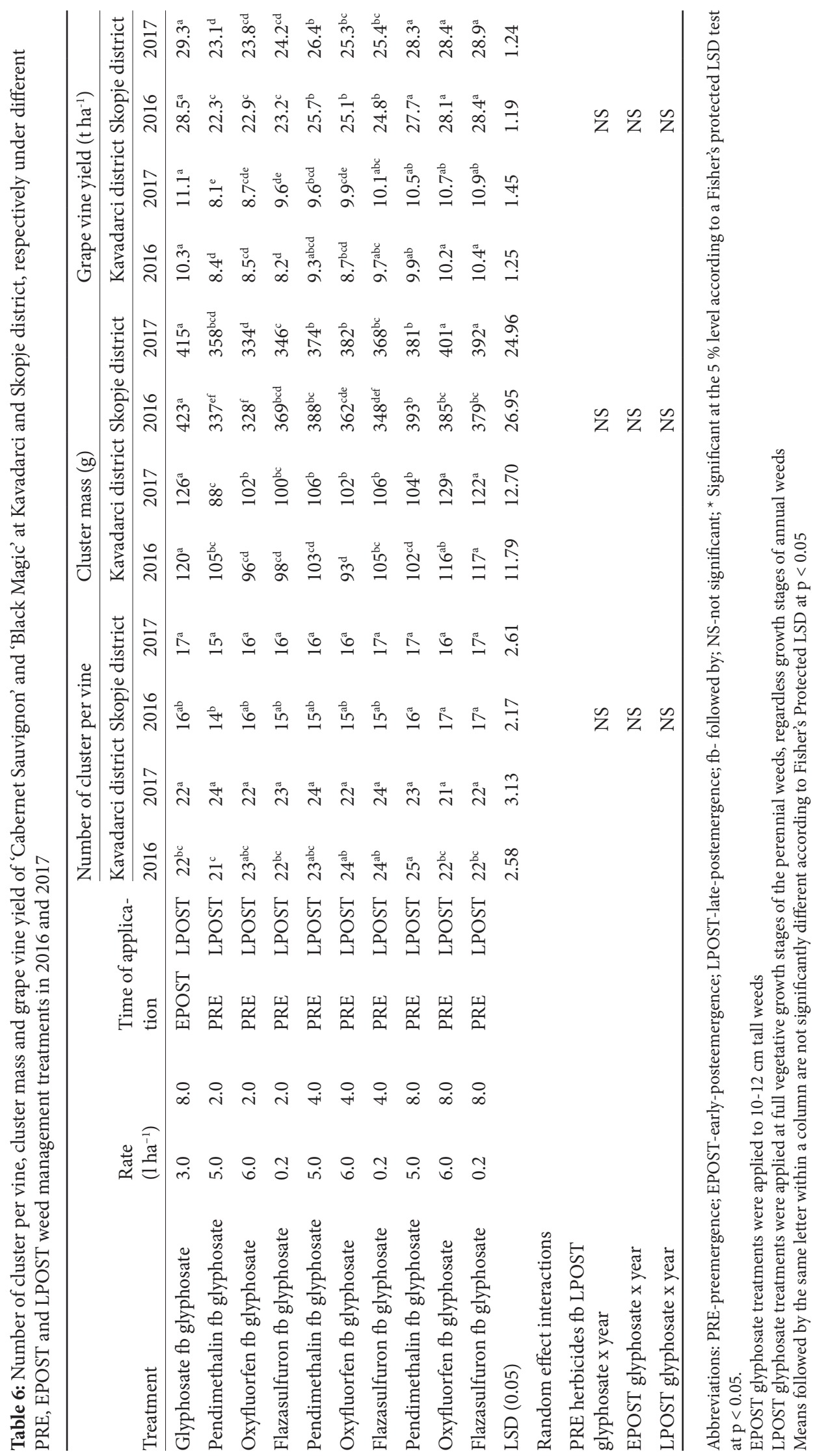




\section{REFERENCES}

Alister, C. A., Gomez, P.A., Rojas, S., and Kogan, M. (2009). Pendimethalin and oxyfluorfen degradation under two irrigation conditions over four years application. Journal of Environmental Science and Health, Part B. 44, 337-343. https://doi.org/10.1080/03601230902800986

Alshallash, K. S. (2014). Effect of pendimethalin, trifluralin and terbutryn on Lolium multiflorum growing with barley during pre-emergence stage. Annals of Agricultural Sciences, 59, 239-242. https://doi.org/10.1016/j.aoas.2014.11.012

Anonymous, 2012. Mission Herbicide. Material Safety Data Shift (MSDS), Summit Agro, USA LLC. http://www.cdms. net/LDat/mpC41001.pdf.

Armel, G. R., Wilson, H. P., Richardson, R. J., and Hines, T. E. (2003). Mesotrione, acetochlor, and atrazine for weed management in corn (Zea mays). Weed Technology, 17(2), 284290. https://doi.org/10.1614/0890-037X(2003)017[0284:M AAAFW]2.0.CO;2

Barba, A., Oliva, J., Garcria, M. A., and Rubio, A. (2003). Leaching of benfluralin, pendimethalin and propyzamide in different soil types. An Experinmental Approach. XII Symposium Pesticide Chemestry (pp. 299-308). June 4-6, Piacenza, Italy.

Baylis, A. D. (2000). Why glyphosate is a global herbicide: Strengths, weaknesses and prospects. Pest Management Science, 56(4), 299-308. https://doi.org/10.1002/(SICI)15264998(200004)56:4<299::AID-PS144>3.0.CO;2-K

Boerboom, C. (2000). Timing postemergence herbicides in corn and soybeans. Wisconsin Crop Management Conference.

Boerboom, C., \& Owen, M. (2006). Facts about glyphosate-resistant eeeds. The glyphosate, weeds, and crops series. GWC1. Purdue Extension.

Bonasia, A., Conversa, G., Lazzizera, C., La Rotonda, P., and Elia, A. (2012). Weed control in lampascione Muscari comosum (L.) Mill. Crop Protection, 36, 65-72. https://doi. org/10.1016/j.cropro.2012.02.001

Chinnusamy N., Chinnagounder, C., and Krishnan, P. N. (2013). Evaluation of weed control efficacy and seed cotton yield in glyphosate tolerant transgenic cotton. American Journal of Plant Sciences, 4(6), 1159-1163. https://doi. org/10.4236/ajps.2013.46142

Chomas, A. J., \& Kells, J. J. (2004). Triazine-resistant common lambsquarters (Chenopodium album) control in corn with preemergence herbicides. Weed Technology, 18, 551-554. https://doi.org/10.1614/WT-03-077R

Dev J., J.N. Singh and G. Singh. 1992. Development and use of a soil bioassay for pendimethalin and fluchloralin. Tropical Pest Management, 38(1), 22-24. https://doi. org/10.1080/09670879209371639

Filipovski, G. (2006). Soil classification of the Republic of Macedonia. MASA, 313-323.

Frans, R.E., Talbert, R., Marx, D., and Crowley, H. (1986). Experimental design and techniques for measuring and analyzing plant responses to weed control practices. In N. D. Camper ed. Research Methods in Weed Science. 3rd ed. Champaign, IL: Southern Weed Science Society, (pp. 3738).
Grey, T.L., \& McCullough, P. E. (2012). Sulfonylurea herbicides' fate in soil: Dissipation, mobility, and other processes. Weed Technology, 26(3), 579-581. https://doi.org/10.1614/WT-D$11-00168.1$

Grey, T., \& Webster, T. (2013). Cotton (Gossypium hirsutum L.) response to pendimethalin formulation, timing, and method of application. Herbicides - Current Research and Case Studies in Use. InTech Publisher. https://doi. org/10.5772/56184

Grove, M. D. (2011). An update on the pending new registrations of flazasulfuron in the United States. Proceedings of the Weed Science Society of America 64 (pp. 196).

Holm, L.G., Donald, P., Pancho, J.V., and Herberger, J. P. (1977). The world's worst weeds: Distribution and biology. (pp. 609) The University Press of Hawaii, Honolulu, Hawai.

Jursík, M., Andr, J., Holec, J. and Soukup, J. (2011). Efficacy and selectivity of post-emergent application of flumioxazin and oxyfluorfen in sunflower. Plant Soil Environment, 57(11), 532-539. https://doi.org/10.17221/285/2011-PSE

Kadir, S., Bauernfeind. R., and Tisserat, N. (2004). Commercial grape production in Kansas. Manhattan (pp. 26). KS: Kansas State University Cooperative Research and Extension publication M2370.

Kadir, S., \& Bauernfeind, R. (2005). Midwest commercial small fruit and grape spray guide. (pp. 55-59). West Lafayette: Purdue University Cooperative Extension Service.

Kadir, S., \& Al-Khatib, K. (2006). Weed control in grape after fall and spring application of selected herbicides. Weed Technology, 20, 74-80. https://doi.org/10.1614/WT-05053R.1

Kaps, M. L., \& Odneal, M. B. (1991). Fall-applied preemergent herbicides in a Missouri vineyard do not control annual weeds the following season. Hortscience, 26(10), 1292-1293. https://doi.org/10.21273/HORTSCI.26.10.1292

Knežević, S. Z., Evans, S. P., Blankenship, E. E., Van Acker, R. C., and Lindquist, J. L. (2002). Critical period for weed control: The concept and data analysis. Weed Science, 50, 773-786. https://doi.org/10.1614/0043-1745(2002)050[0773:CPFW CT]2.0.CO;2

Kostov, T. (2006). Herbology. Scientific Book. (pp. 371). The University Press of the Republic of Macedonia, Skopje.

Leak, S. (2013). Flazasulfuron - A new total herbicide for amenity areas. http://www.aab.org.uk/images/LEAK.pdf.

Lopes Ovejero, R. F., Soares, D. J., Oliveira, W. S., Fonseca, L. B., Berger, G. U., Soteres, J. K., and Christoffoleti, P. J. (2013). Residual herbicides in weed management for glyphosateresistant soybean in Brazil. Planta Daninha, 31(4), 947-959. https://doi.org/10.1590/S0100-83582013000400021

Lyon, D.J., \& Wilson, R. G. 2005. Chemical weed control in dryland and irrigated chickpea. Weed Technology, 19(4), 959965. https://doi.org/10.1614/WT-05-013R.1

Montgomery, D., Evans, C., and Martin, D. (2010). Valuation of nicosulfuron, flazasulfuron and MSMA for johnsongrass control in bermudagrass roadsides. Oklahoma Department of Transportation.

Mitchem, W. E., \& Monks, D. W. (2005). Weed management for southeast vineyards. Horticulture Information Leaflet 205- 
C. College of Agriculture \& Life Sciences Department of Horticultural Science.

Monsanto Company (2005). 2005 Technology Use Guide (pp. 27-28). St. Louis, MO.

Nieto, J., Guida, G., and Corbellini, G. (1998). Flazasulfuron (Chikara $25 \mathrm{WG}$ ), nuova sulfonilurea per il controllo delle malerbe presenti su vite, agrumi, olivo ad incolti. ATTI Giornale Fitopatologiche, 345-350.

Novosel, K. M., Renner, K. A., Kells, J.J., and Spandl, E. (1998). Metolachlor efficacy as influenced by three acetolac-tate synthase-Inhibiting herbicides. Weed Technology, 12, 248253. https://doi.org/10.1017/S0890037X00043761

Nurse, R. E., Swanton, C. J., Tardif, F. J., and Sikkema, P. H. (2006). Weed control and yield are improved when glyphosate is preceded by a residual herbicide in glyphosate-tolerant maize (Zea mays). Crop Protection, 25(11), 1174-1179. https://doi.org/10.1016/j.cropro.2006.02.015

Patil, D. R., Sulikeri, G. S., and Pati, H. B. (2008). Studies on the weed Management practices in thompson seedless grape vineyard. ISHS Acta Horticulturae 785: International Symposium on Grape Production and Processing, Baramati (Pune). Maharashtra, India. https://doi.org/10.17660/ActaHortic. 2008.785.40

Pool, R. M., Dunst., R. M., and Lasko, A. N. (1990). Comparison of sod, mulch, cultivation, and herbicide floor management practices for grape production in nonirrigated vineyards. Journal of the American Society for Horticultural Science, 115, 872-877. https://doi.org/10.21273/JASHS.115.6.872

Raimondi, M. A., Oliveira, JR. R. S., Constantin, J., Biffe, D. F., Arantes, J. G. Z., Franchini, L. H., Rios, F. A., Blainski, E., and Osipe, J. B. (2010). Residual activity of herbicides applied to the soil in relation to control of four Amaranthus species. Planta Daninha, 28, 1073-1085. https://doi. org/10.1590/S0100-83582010000500015

Ramsey, F. L., \& Schafer, D. W. (1997). The statistical sleuth: A course in methods of data analysis. Belmont, (pp, 91-97). CA: Duxbury.

Sanguankeo, P. P., Leon, R.G., and Malone, J. (2009). Impact of weed management practices on grapevine growth and yield components. Weed Science, 57, 103-107. https://doi. org/10.1614/WS-08-100.1
Singh, M., Ramirez, A. H. M., Jhala, A. and Malik, J. M. (2012). Weed control efficacy and citrus response to flazasulfuron applied alone or in combination with other herbicides. American Journal of Plant Sciences, 3, 520-527. https://doi. org/10.4236/ajps.2012.34062

Stewart, C. L., Soltani, N., Nurse, R. E., Hamill, A. S., and Sikkema, P.H. (2012). Precipitation influences pre- and postemergence herbicide efficacy in corn. American Journal of Plant Sciences, 3, 1193-1204. https://doi.org/10.4236/ ajps.2012.39145

Swanton, C. J., Weaver, S., Cowan, P., Van Acker, R., Deen, W., and Shreshta, A. (1999). Weed thresholds: theory and applicability. Journal of Crop Production, 2, 9-29. https://doi. org/10.1300/J144v02n01_02

Taylor-Lovell, S., Wax, L. M., and Bollero, G. (2002). Preemergence flumioxazin and pendimethalin and postemergence herbicide systems for soybean (Glycine max). Weed Technology, 16(3), 502-511. https://doi.org/10.1614/0890-037X( 2002)016[0502:PFAPAP]2.0.CO;2

Tomlin, C. D. S. (2000). Flazasulfuron. In: Tomlin, C.D.S. (Ed.), The Pesticide Manual, 12th ed. British Crop Protection Council (pp. 417-418). Surrey (UK).

Yen, J., Sheu, W., and Wang, Y. (2003). Dissipation of the herbicide oxyfluorfen in subtropical soils and its potential to contaminate groundwater. Ecotoxicology and Environment Safety, 54, 151-156. https://doi.org/10.1016/S01476513(02)00048-9

Ying, G., \& Williams, B. (2000). Dissipation of herbicides in soil grapes in South Australian vineyard. Agriculture, Ecosystem and Environment, 78, 283-289. https://doi.org/10.1016/ S0167-8809(99)00127-9

Zabadal, T.J., \& Dittmer, T.W. (1994). Setting priorities for vine management in a new vineyard planting. Proc. $9^{\text {th }}$ Annual Midwest Regionl Grape and Wine Conference (pp, 63-66).

Đurović, R., Gajić-Umiljendić, J., and Đorđević, T. (2008). Determination of atrazine, acetochlor, clomazone, pendimethalin and oxyfluorfen in soil by a solid phase microextraction method pestic. Phytomedicine, 23, 265-271. https://doi.org/10.2298/PIF0804265D 